\title{
Duodenal atresia with apple peel associated with congenital diaphragmatic hernia: an exceptional case and a literature review
}

\author{
J.A. Molino Gahete, S. López Fernández, B. Oliver, H. Boix, O. Rocha, M. López, G. Guillén \\ Oncological and Neonatal Surgery Unit. Pediatric Surgery Department. Vall d'Hebrón University Hospital. Barcelona (Spain).
}

\begin{abstract}
Introduction. Duodenal atresia associated with apple peel is extremely rare. Duodenal atresia occurs as a result of absence of recanalization at an early stage, whereas intestinal atresia is seemingly due to vascular causes at later stages. The presence of abnormalities associated with diaphragmatic hernia is frequent, but association with duodenal atresia has been little explored.

Case report. This is the case of a female neonate born at gestational week 31, with duodenal atresia and apple peel, associated with left diaphragmatic hernia and major heart disease. An abdominal muscle flap was performed for diaphragmatic defect closure purposes, and duodenojejunal anastomosis was carried out following resection of part of the non-viable apple peel.

Discussion. To our knowledge, this is the first case described with this rare association. The combination of duodenal atresia and apple peel had been previously described 11 times. However, the association of both with congenital diaphragmatic hernia had not been reported yet.
\end{abstract}

KeY Words: Duodenal atresia; Intestinal atresia; Apple peel; Congenital diaphragmatic hernia; Congenital malformation.

\section{ATRESIA DUODENAL CON APPLE PEEL ASOCIADA A HERNIA DIAFRAGMÁTICA CONGÉNITA: UN CASO EXCEPCIONAL Y REVISIÓN DE LA LITERATURA}

\section{RESUMEN}

Introducción. La atresia duodenal asociada con appel peel es extremadamente infrecuente. La primera se produce por un defecto en la recanalización en etapas tempranas, mientras que la atresia intestinal parece deberse a causas vasculares en etapas más tardías. La presencia de anomalías asociadas a la hernia diafragmática es común, pero la asociación con la atresia duodenal apenas está descrita.

Caso clínico. Presentamos un recién nacido de 31 semanas de gestación y sexo femenino, con atresia duodenal y apple peel, asociada a hernia diafragmática izquierda y cardiopatía mayor. Se realizó

DOI: $10.54847 /$ cp.2022.01.16

Corresponding author: Dr. José Andrés Molino Gahete.

E-mail address: jamolino@ vhebron.net

Date of submission: November 2020 Date of acceptance: May 2020 un flap muscular abdominal para el cierre del defecto diafragmático y anastomosis duodenoyeyunal tras la resección de parte del apple peel inviable.

Comentarios. A nuestro entender, es el primer caso descrito con esta asociación singular. La combinación de atresia duodenal con apple peel se ha descrito previamente en 11 ocasiones; la asociación de ambas con hernia diafragmática congénita no había sido descrita.

Palabras Clave: Atresia duodenal; Atresia intestinal; Apple peel; Hernia diafragmática congénita; Malformación congénita.

\section{INTRODUCTION}

Duodenal atresia is the most common congenital cause of neonatal intestinal obstruction. With an incidence of 1 in 5,000-10,000 newborns, it accounts for half of intestinal atresias $^{(1)}$. Absence of recanalization from gestational week (GW) 6 is one of the most widely accepted theories ${ }^{(2)}$.

However, intestinal atresia is caused by an interruption of vascular supply at later gestational stages ${ }^{(3,4)}$. Type IIIb intestinal atresia, known as apple peel, represents approximately $5 \%$ of jejunoileal atresias ${ }^{(1)}$. The association of duodenal atresia with apple peel intestinal atresia is extremely rare, with only 11 cases reported the literature up until now.

Congenital diaphragmatic hernia occurs in 1 in 2,5003,500 newborns. The association with other malformations is common, with heart malformations being the most frequent, whereas the association with gastrointestinal malformations is rare ${ }^{(5)}$. The association of congenital diaphragmatic hernia with duodenal atresia has been little explored ${ }^{(6)}$.

The association of the three malformations has no satisfactory embryological explanation in terms of pathogenesis, which suggests it may have a genetic origin. The association of familial intestinal atresia - primarily apple peel - with fibroblast growth factor receptor 2IIIb and fibroblast growth factor 10 (Fgfr2b/Fgf10)(7), as well as the association of familial apple peel and heart disease with NOTCH1 gene mutations ${ }^{(8)}$, have been described. 


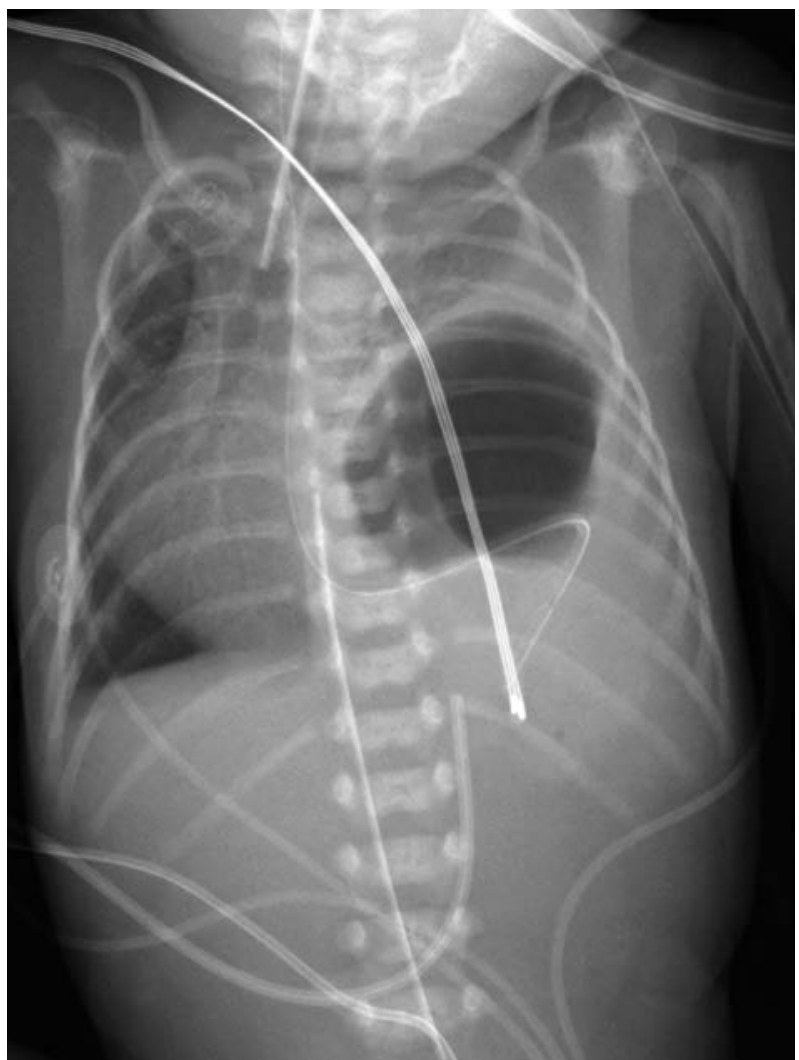

Figure 1. Thoraco-abdominal X-ray at birth: congenital left diaphragmatic hernia, and great air bubble at the left hemithorax, without abdominal air.

This is the case of a pre-term newborn with congenital diaphragmatic hernia and major heart disease associated with duodenal atresia with "apple peel".

\section{CASE REPORT}

29-year-old mother with monochorionic diamniotic twin gestation. The first twin, who was a female, had polyhydramnios and was prenatally diagnosed with left diaphragmatic hernia, potentially with small bowel, stomach, and liver herniation [Lung-to-Head Ratio (LHR): 1.7; o/e LHR: $40 \%]$. She also had an echogenic image of a dilated intestinal loop in the chest, suggestive of upper intestinal obstruction, at second- trimester ultrasound examination.

At gestational week $31+4$, a uterine cesarean section was carried out. The newborn weighted 1,300 grams and had an Apgar score of 5/7/7. At baseline X-ray, left diaphragmatic hernia and gastric dilatation were confirmed, without abdominal air (Fig. 1). In addition, prenatal diagnosis of heart disease - tetralogy of Fallot with double-outlet right ventricle - was confirmed.

Following stabilization, she underwent left transverse supraumbilical laparotomy at the age of three days.

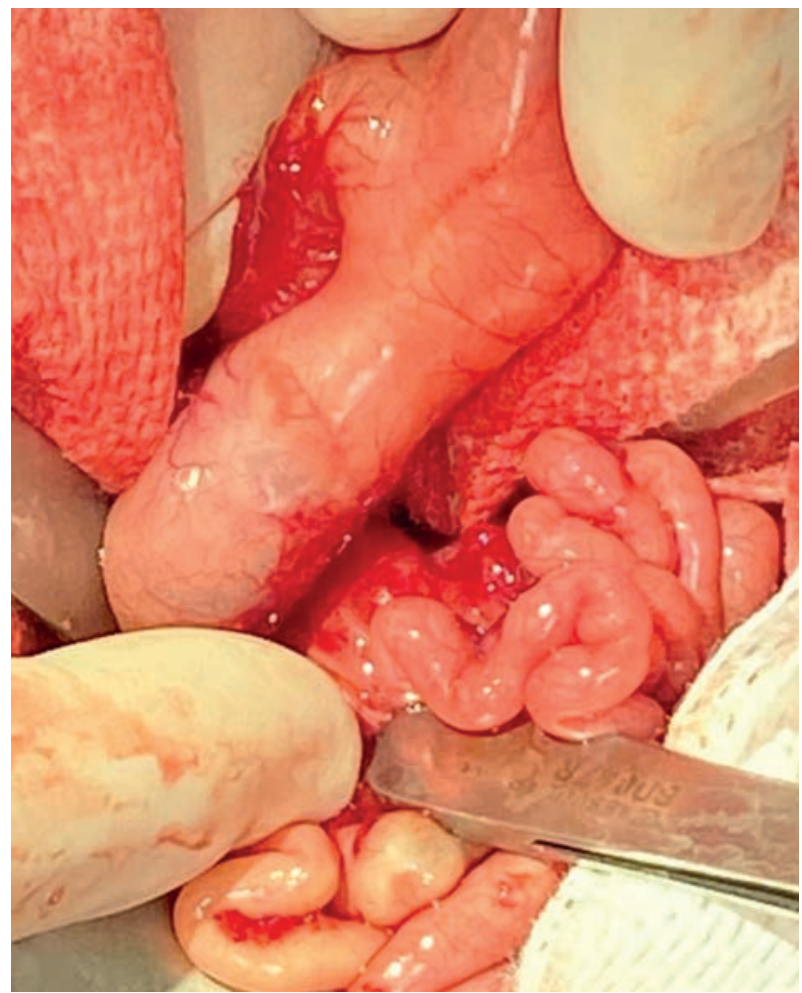

Figure 2. Postampullary type III duodenal atresia.

It revealed an almost total left diaphragmatic agenesis, which required an abdominal muscle flap with the internal oblique and transverse oblique muscles for defect closure purposes. Abdominal muscle flap, which has already been described in the literature ${ }^{(9)}$, is the technique of choice at our healthcare institution.

Once herniated organs had been reduced, great gastric dilatation was found, along with post-ampullary atresia, which did not involve the rest of the small bowel (Fig. 2). At the level of the jejunum, it had an apple peel appearance. Once the first $50 \mathrm{~cm}$ of non-viable apple peel had been resected, duodenojejunal anastomosis was carried out, while preserving $85 \mathrm{~cm}$ of small bowel down to the ileocecal valve (Fig. 3).

The patient remained intubated for 10 days as a result of pulmonary hypoplasia and baseline heart disease, with total or partial parenteral nutrition until she was 19 days old, when full enteral nutrition was achieved (34 corrected $\mathrm{GWs})$. She was discharged at the age of 115 days, with a weight of $3.430 \mathrm{~kg}$.

A genetic study was carried out. It confirmed they were monozygotic twins, with the patient showing no remarkable genetic disorders as compared to her sister.

When she was admitted for the second time, she underwent heart surgery as a result of having severe hypoxic crises primarily caused by heart disease, not by pulmonary hypoplasia. A systemic-pulmonary fistula was created, both 


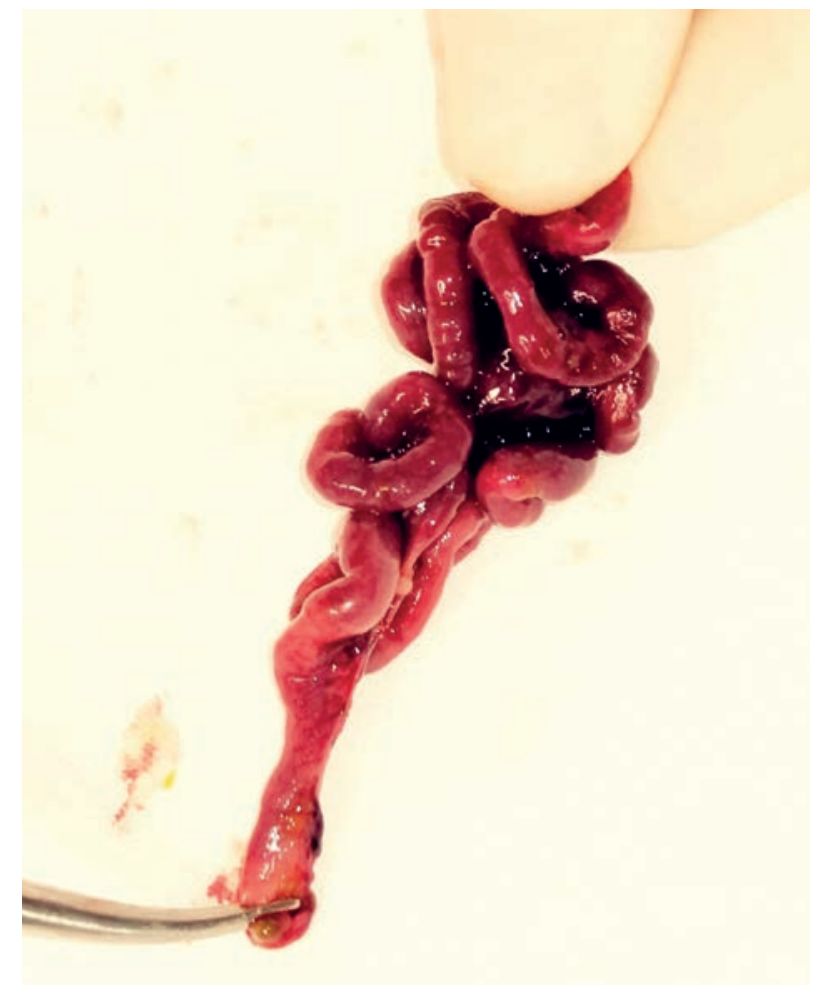

Figure 3. Apple peel segment resected (proximal jejunum).

pulmonary veins were dilated, and the ductus arteriosus was closed. She required postoperative support - extracorporeal membrane oxygenation - for 4 days.

Today, the patient is 10 months old. Weight and size gain is adequate, and tolerance to enteral nutrition is correct, alternating oral nutrition with nasogastric tube nutrition as a result of suction and deglutition disorders.

\section{DISCUSSION}

Congenital diaphragmatic hernia is a relatively common malformation which occurs in 1 in 2,500-3,500 newborns. As in this case, most of them are left posterolateral congenital diaphragmatic hernias. Defect size may range from a small hernia orifice to diaphragmatic agenesis, and it determines the type of repair required, the degree of pulmonary hypoplasia, and ultimately, prognosis.

Etiology is unclear, but even though there are hereditary cases and cases associated with syndromes and chromosomal disorders, it is widely regarded as sporadic. It is frequently $-20-60 \%$ of cases according to the various series - associated with other malformations, with heart disease being the most common one, followed by genitourinary and musculoskeletal malformations. The association with gastrointestinal malformations is infrequent, with a prevalence below $5 \%(5)$.
In the series published by Zaiss et al., the most frequent malformations were cardiovascular malformations, which occurred in $50.4 \%$ of patients. Contrarily to what had been published in previous series, gastrointestinal malformations were the second most frequent group, as they were present in $21 \%$ of patients - they accounted for $11.4 \%$ of all associated malformations when divided by body systems. Within gastrointestinal malformations, Meckel's diverticulum and anal atresia were the most frequent ones ${ }^{(10)}$. Neither this series nor the previous one described association with duodenal atresia ${ }^{(5)}$.

Castle et al. reported the first case of a patient with VACTERL-like association, which consisted of hemivertebra, clinodactyly, imperforate anus, duodenal atresia, and right diaphragmatic hernia with hepatopulmonary fusion. They also mentioned other exceptional cases of newborns with diaphragmatic hernia and duodenal atresia( ${ }^{(6)}$.

Duodenal atresia has an incidence of 1 in 5,000-10,000 newborns. It is the most common cause of neonatal congenital obstruction, and in most cases, obstruction is post-ampullary. Even though current survival rates exceed $90 \%$, prematurity or association with major abnormalities - primarily heart and chromosomal disorders -may compromise prognosis. It can be associated with annular pancreas or intestinal malrotation in up to $30 \%$ of cases, but association with jejunoileal intestinal atresia occurs in less than $5 \%$ of cases $^{(1)}$.

Intestinal atresia has an incidence of 0.7-0.8 in 10,000 newborns. 5\% of jejunoileal atresias are known as "apple peel". Apple peel occurs as a proximal atresia, usually at the level of the jejunum, with the distal small bowel being rolled up like a spiral around the nutrient mesenteric vessel. The importance of this type of atresia lies in the fact it may require a more complex surgery and give rise to short bowel syndrome ${ }^{(3,4)}$.

One of the most widely accepted hypotheses to explain why the association of duodenal atresia with intestinal atresia is so rare has to do with the different embryological etiologies they have. In the case of duodenal atresia, absence of duodenal recanalization from GW 6 is a commonly accepted theory ${ }^{(2)}$. However, the other intestinal atresias occur due to an interruption of vascular supply at later stages $^{(3,4)}$. In the case of the duodenum, the double vascular supply both from the superior mesenteric artery and the celiac trunk through the gastroduodenal artery makes the occurrence of duodenal atresia as a result of a vascular cause less likely(11).

This is why the association of duodenal atresia with intestinal atresia is infrequent, and the association with apple peel intestinal atresia is extremely rare. Up until now, only 11 cases have been published in the literature ${ }^{(7,11-20)}$. Our patient is number 12 , and the only one with congenital diaphragmatic hernia (Table I).

In addition to the embryological etiology, other genetic factors have been described as a potential cause of intesti- 
Table I. Duodenal atresia with apple peel. A literature review.

\begin{tabular}{clccl} 
Case & Author & Year & $G W$ & Associated abnormalities \\
\hline 1 & Weber et al. & 1999 & 36 & Absent SMA. Down's syndrome. IVC \\
\hline 2 & Arbell et al. & 2006 & 32 & Choledochal cyst. Malrotation \\
\hline 3 & Tatekawa et al. & 2007 & 36 & Multiple intestinal atresia \\
\hline 4 & Ahman et al. & 2009 & 34 & Absent SMA \\
\hline 5 & Patil et al. & 2011 & 33 & Malrotation \\
\hline 6 & Altokhais et al. & 2014 & 33 & Absent SMA. Malrotation. Microphthalmia \\
\hline 7 & Alnosair et al & 2014 & 31 & Absent SMA \\
\hline 8 & Pathak et al. & 2014 & 33 & \\
\hline 9 & Sasa et al. & 2016 & 29 & Absent SMA \\
\hline 10 & Ben Hamida et al. & 2016 & 34 & Absent SMA. Abdominal situs inversus. Multiple intestinal atresia \\
\hline 11 & Kirtane et al. & 2019 & 36 & IAC \\
\hline 12 & Molino et al. & 2020 & 31 & Left CDH. Tetralogy of Fallot with double-outlet RV \\
$\begin{array}{l}\text { GW: gestational week; SMA: superior mesenteric artery; } \\
\text { diaphragmatic hernia; } \text { RV: right ventricle. }\end{array}$ & &
\end{tabular}

nal atresia, both apple peel and familial duodenal atresia. The combination of both, as well as the presence of familial atresia as a result of hereditary genetic abnormalities, is extremely rare. Fibroblast growth factor receptor 2IIIb and fibroblast growth factor 10 (Fgfr2b and Fgf10) are relevant regulatory molecules for mesenchymal-epithelial interactions, and they are involved in the pathogenesis of intestinal atresia( ${ }^{(7)}$.

No homozygous or heterozygous deletion of Fgfr $2 b$ and Fgf10 was noted in our patient.

NOTCH1 gene has also been described to be involved in left obstructive congenital heart disease, predominantly stenosis of the aortic valve and the bicuspid aortic valve, aortic coarctation and hypoplastic left heart, and association with extracardiac vascular abnormalities and apple peel, with embryonic vascular disease standing as the cause of such defect ${ }^{(8)}$. Tetralogy of Fallot with double-outlet right ventricle was the associated heart disease in our patient. No NOTCH1 gene variants were detected.

In conclusion, the association of duodenal atresia with apple peel is extremely rare. Even though the association of gastrointestinal abnormalities with congenital diaphragmatic hernia has already been reported, to our knowledge, the combination of the three malformations had never been described in the literature.

\section{REFERENCES}

1. Dalla Vecchia LK, Grosfeld JL, West KW, Rescorla FJ, Scherer LR, Engum SA. Intestinal atresia and stenosis: a 25-year experience with 277 cases. Arch Surg. 1998; 133(5): 490-6; discussion 496-7.
2. Tandler J. Zur. Entwickelungsgeschichte des menschlichen duodenum in fruhen Embryonalstadien. Morph Jahrb. 1900; 29: 187-216.

3. Louw JH, Barnard CN. Congenital intestinal atresia; observations on its origin. Lancet Lond Engl. 1955; 269(6899): 1065-7.

4. Santulli TV, Blanc WA. Congenital atresia of the intestine: pathogenesis and treatment. Ann Surg. 1961; 154: 939-48.

5. Sweed Y, Puri P. Congenital diaphragmatic hernia: influence of associated malformations on survival. Arch Dis Child. 1993; 69(1 Spec No): 68-70.

6. Castle SL, Naik-Mathuria BJ, Torres MB. Right-sided congenital diaphragmatic hernia, hepatic pulmonary fusion, duodenal atresia, and imperforate anus in an infant. J Pediatr Surg. 2011; 46(7): 1432-4.

7. Tatekawa Y, Kanehiro H, Nakajima Y. Duodenal atresia associated with 'apple peel' small bowel without deletion of fibroblast growth factor-10 or fibroblast growth factor receptor $2 \mathrm{IIIb}$ : report of a case. Surg Today. 2007; 37(5): 430-3.

8. Digilio MC, Magliozzi M, Di Pede A, Valfrè L, Dentici ML, Auriti C, et al. Familial aggregation of 'apple peel' intestinal atresia and cardiac left-sided obstructive lesions: A possible causal relationship with NOTCH1 gene mutations. Am J Med Genet A. 2019; 179(8): 1570-4.

9. Molino JA, García Martínez L, Guillén Burrieza G, Peiró Ibáñez JL, López-Fernández S, Laín A, et al. Outcomes after Split Abdominal Wall Muscle Flap Repair for Large Congenital Diaphragmatic Hernias. Eur J Pediatr Surg Off J Austrian Assoc Pediatr Surg Al Z Kinderchir. 2020; 30(2): 210-4.

10. Zaiss I, Kehl S, Link K, Neff W, Schaible T, Sütterlin M, et al. Associated malformations in congenital diaphragmatic hernia. Am J Perinatol. 2011; 28(3): 211-8.

11. Weber DM, Freeman NV. Duodenojejunal atresia with apple peel configuration of the ileum and absent superior mesenteric artery: observations on pathogenesis. J Pediatr Surg. 1999; 34(9): 1427-9. 
12. Arbell D, Orkin B, Naveh Y, Gur I, Udassin R. Duodenojejunal atresia with absent dorsal mesentery, choledochal cyst, and malrotation in a premature newborn-a case report. J Pediatr Surg. 2006; 41(6): e11-3.

13. Ahmad A, Sarda D, Joshi P, Kothari P. Duodenal atresia with 'apple-peel configuration' of the ileum and absent superior mesenteric artery: a rare presentation. Afr J Paediatr Surg AJPS. 2009; 6(2): 120-1.

14. Patil RT, Gupta R, Parelkar SV, Oak S, Sanghvi B, Prakash A, et al. A rare case of duodenal atresia with apple-peel configuration of the small intestine and malrotation. Eur J Pediatr Surg Off J Austrian Assoc Pediatr Surg Al Z Kinderchir. 2011; 21(5): 340-2.

15. Altokhais TI. Duodenal atresia with apple-peel jujenoilial deformity: Case report and review of the literature. J Pediatr Surg Case Rep. 2014; 2(3): 156-8.

16. Alnosair AA, Naga MI, Abdulla MR, Al-Salem AH. Congenital duodenal atresia with 'apple-peel configuration' of the small intestines and absent superior mesenteric artery: A case report and review of literature. J Pediatr Surg Case Rep. 2014; 2(5): 215-8.

17. Pathak M, Narula D. A case of duodenal atresia with apple peel appearance: challenging the current embryology. J Clin Neonatol. 2014; 3(2): 112-4.

18. Saša RV, Ranko L, Snezana C, Lidija B, Djordje S. Duodenal atresia with apple-peel configuration of the ileum and absent superior mesenteric artery. BMC Pediatr. 2016; 16(1): 150.

19. Ben Hamida H, Hadj Salem R, Ben Ameur K, Rassas A, Chioukh FZ, Sakka R, et al. Duodenal Atresia Associated with Apple Peel Atresia and Situs Inversus Abdominus: A Case Report. J Neonatal Surg. 2016; 5(4): 60.

20. Kirtane JM, Bhange SA, Nabi F, Shah V. Duodenal atresia with familial apple peel syndrome: case study with review of literature. BMJ Case Rep. 2019; 12(8): e230160. 